\title{
PARAMETRIC ANALYSIS OF THE SENSITIVITY OF A PRESTRESSED CONCRETE BEAM USING THE DOE SIMULATION TECHNIQUE
}

\author{
SZ. WOLIŃSKI ${ }^{1}$, T. PYTLOWANY ${ }^{2}$
}

\begin{abstract}
The paper presents the method of simplified parametric analysis of the sensitivity of a pre-tensioned concrete beam. The presented approach is based on the DOE (design of experiments) data collection which is simulation technique allowing for identification of variables deciding about the effectiveness and costs of designed structures. Additionally, application of the hyper-surface of the construction response allows designers to the development of multi-dimensional trade-off graphs to facilitate, the assessment of the scope of changes in random state variables permitted due to the adequate criteria and selection of their values close to optimum. Design basics, procedures and results of the presented considerations of sensitivity assessment and reliability of the structure has been shown on the example of a pre-stressed concrete beam designed in accordance with the requirements and procedures of Eurocode 2
\end{abstract}

Keywords: design of experiments DOE, pre-tensioned concrete beam, sensitivity assessment, reliability of the structure

\section{INTRODUCTION}

Analysis of the impact of changes in value and uncertainty of chosen design variables on characteristics of the state of the prestressed concrete structure has been presented by authors of this paper in the article [1]. It became an inspiration for further research related to the sensitivity analysis of prestressed structures. This time, the research attempts to simplified sensitivity analysis of the pre-tensioned beam. Structures have to be designed to satisfy two basic criteria; ultimate limit states (ULS) and serviceability limit states (SLS). Reinforced concrete structures are generally designed to satisfy ULS and checked to make sure that they behaves satisfactorily at SLS. In

\footnotetext{
${ }^{1}$ Assoc. prof., PhD, Eng., Faculty of Civil and Environmental Engineering and Architecture, Rzeszow University of Technology, Poznanska 2, budynek P, 35-084 Rzeszów, Poland, e-mail: szwolkkb@prz.edu.pl

${ }^{2} \mathrm{PhD}$, Eng., Polytechnic Institute, Krosno State College, Rynek 1, 38-400 Krosno, Poland, e-mail: tompyt@pwsz.krosno.pl
} 
reverse, prestressed concrete structures are generally designed to satisfy SLS because generally, but not always, these structures designed for serviceability have adequate safety at ULS. The traditional shaping and design of pre-tensioned concrete beams is usually related to intuitive optimization based on experience and good practices and aiming to meet the assumed requirements as much as possible. The analysis of sensitivity of the structure to random changes in the parameters of state function may be then helpful. With development of computational methods, simple MES computer programs have been replaced by more advanced ones. The use of the finite element method brings benefits that outweigh the costs incurred after a short time. It becomes possible to design optimal constructions in many ways (e.g. with a minimum weight, resistant to specific impacts and influences, etc.), the number of expensive prototypes decreases and the time of introduction of a prefabricate product to the market is shortened. A thorough analysis of examples of applications of these methods in practice sometimes raises quite large reservations. This is mainly due to the approximate nature of the solutions obtained, as well as the uncertainty associated with the choice and determination of: selection criteria, parameters of optimization variables and restrictions on their variability. In the ANSYS software for scientific applications in the Design Explorer module, "what-if" parametric analysis (i.e. simplified sensitivity analysis) can be conducted in order to check the construction response to changes of specific parameters and the range of these changes. It is also possible to carry out probabilistic analysis to estimate values of an assumed reliability measure and to assess safety of a structure, as well as to determine multiple correlations between input and output variables. It is also possible to determine, by Monte-Carlo simulation methods, the approximate response surface of the structure to the adopted virtual experiment plan and obtain trade-off graphs showing correctness of solutions obtained in the adopted design space. The paper presents a short description of the method of analysis of the impact of value changes and uncertainty of chosen design variables on the characteristics of pre-tensioned concrete structures based on parametric analysis of "what-if sensitivity" and " trade-off graphs", using simulation data collection technique (DOE - Design Of Experiments) to build the surface of the construction response. This technique can also be applied to determine a matrix of coefficients of correlation for state variables of the analyzed system, i.e. to estimate values of coefficients of correlation between input and output variables. The assumptions, procedures and results of using the DOE technique to assess sensitivity and reliability of structures are presented on the example of a uniformly loaded pre-tensioned concrete I-shape beam. Variables characterizing the state of the structure are the following: load applied to the top flange of the pre-tensioned concrete beam $G$ $[\mathrm{kN} / \mathrm{m}]$, prestressing force including loss of prestress caused by concrete creep and shrinkage, and 
relaxation of the prestressing steel $\mathrm{S}[\mathrm{kN}]$, modulus of elasticity depending on the concrete age $\mathrm{Y}$ [GPa] meaning from the initial stage, after the concrete has obtained compressive strength min. 45 $\mathrm{MPa}$, up to 50 years and a global safety factor GlS. The obtained results, in the form of response surfaces, sensitivity and trade-off diagrams, allow to determine the hierarchy of impact of variables included in the analysis and areas of unfavourable interaction of these variables affecting selected parameters characterizing the safety state of the structure.

\section{COMMENTS ON THE PARAMETRIC ANALYSIS OF STRUCTURE SENSITIVITY WITH THE DOE TECHNIQUE}

Finding the optimal solution that meets the requirements of current design standards is a task in which several trade-offs should be taken into account. This requires a lot of expert knowledge, implementation of specific professional software and a large amount of work.

Building structures are subjected to various loads and actions- Sensitivity analysis of their structures is used to determine deviations of considered $\Delta y(\boldsymbol{x})$ state characteristics (e.g. load capacity, displacement, vibration frequency, etc.) for a given value of $\boldsymbol{x}_{o}$ design variable vectors and assumed increase $\Delta \boldsymbol{x}$ in their values. In relation to constructions made of prestressed concrete, the sensitivity analysis consists in determining the impact of deviations in values of state variables, e.g. destructive loads, internal forces, frequency of natural vibrations, geometrical data and others, on the behavior of the structure.

The most widespread in engineering practice is the so-called parametric sensitivity analysis. It consists in calculating the value of selected characteristics of the state of the structure for several or even over a dozen arbitrarily set design variables and the relation of their increments on changes of the state of structure lying on the surface of the response. This allows to roughly assess the behavior of the structure. Obtaining and appropriately applying description of the response of the structure on the attempt to optimize or build trade-off graphs can, however, lead to serious errors.

Designing the structure by the surface response method allows to define acceptable ranges of variables (also random variables) for which the design requirements are met, as well as to determine the optimal combination of these changes for the set requirements, criteria and constraints [3]. The correct approximation or interpolation of the response surface with acceptable accuracy requires, in case of real constructions, multiplicated calculations of construction response values (deflections, 
capacities, etc.) for different combinations of state variable increments, that is, the implementation of a sufficiently large number of virtual experiments.

The calculations are made using appropriate FEM programs but due to non-linear nature, multidimensionality of the construction models and random nature of most state variables, cost of their implementation is so high that it is necessary to use the Monte Carlo simulation method to limit time and costs of calculations (MC) using reduction techniques developed within the mathematical theory of experiments. In the ANSYS DesignXplorer [4,5] program module the DOE (Design Of Experiments) technique was used in order to determine the relationship between design variables and structure behaviour. It is based on the experiment plan known as Latin hypercube sampling, what makes possible a significant reduction of the number of calculation results necessary to achieve the assumed accuracy of determining the response surface $[5,6]$, compared to the basic MC method.

Knowing the response surface of the structure allows to clearly present the relationship between input design variables and output variables using graphs that make it possible to understand the behaviour of the structure in different situations and determine necessary changes to be made to meet specific requirements.

A very useful way of using the results of calculations made to determine the response surface of the construction is to develop trade-off graphs showing the acceptability of solutions in a specific design space. For each design variable value $\boldsymbol{x}_{\boldsymbol{i}}$ or a group of such variables $\boldsymbol{x}_{1}, \boldsymbol{x}_{2}, . ., \boldsymbol{x}_{\boldsymbol{n}}$ from the assumed variability area, the result of the calculation of the response $\boldsymbol{i}_{\boldsymbol{n}}$ of the structure is plotted as a single point. The set of all calculation results $\boldsymbol{y}_{1}, \boldsymbol{y}_{2}, \ldots, \boldsymbol{y}_{\boldsymbol{k}}$ determines the area of possible structure states, in which it is possible to separate acceptable solutions that meet the assumed criteria $[7,8]$ in various degrees and indicate solutions close to the optimal one. Application of the experiment plan based on the Latin hypercube sampling, i.e. random selection of values of design variables from the assumed variability area for which the structure response is calculated, allows to estimate the elements of correlation matrix which are values of coefficients of correlation between each pair of variables included in the calculations. Knowing the value of the correlation measure makes it possible to assess the influence of increasing or decreasing impact of design variables on the characteristics of the state of the structure and the synergy effect. This information facilitates designer's decision how to modify the design in order to obtain a solution close to the optimal one. 


\section{WORKING EXAMPLE OF SENSITIVITY ANALYSIS OF PRE-TENSIONED BEAM}

The object of the DOE analysis is a pre-tensioned concrete beam with the span of $12 \mathrm{~m}$, made of concrete strength class $\mathrm{C} 45 / 55$. The beam is pre-stressed with fourteen tendons, with relaxation class 2; with a cross-sectional surface of a strand equal $38 \mathrm{~mm}^{2}$. Nominal tensile strength of the strand $\mathrm{R}_{\mathrm{m}}=1860 \mathrm{MPa}$, and characteristic yield stress of reinforcing steel $\mathrm{f}_{\mathrm{yk}}=500 \mathrm{MPa}$ [9]. While designing pre-stressed concrete constructions, requirements regarding compressive strength of concrete as well as the values of the modulus of elasticity should be defined at the moment of anticipated load on the structure. Hence, determination of the acceptable scope of this variable depends on the time $\mathrm{t}$ [days].

An evenly distributed load is applied to the top flange of the pre-tensioned concrete beam. Numerical calculations presented in this chapter were made using the "Ansys" program [4]. The finite element "SOLID 65" has been used for modelling of 3D concrete. The element is defined by 8 nodes with 3 degrees of freedom for the considered analysis. Destruction criterion in case of the action of a complex state of stress and strain was adopted according to the following criteria: shear transfer coefficient for open crack is 0.3 and for closed crack 1.0, uniaxial tensile strength in uniaxial tension is $3.8 \mathrm{MPa}$.

For modelling reinforcing bars the "LINK 180", uniaxial compression element with 3 degrees of freedom in each node has been used. Steel bars and concrete are tied by means of knots that connect selected nodes of one region with selected elements from another region. The "SHELL 181" element was used to model the tendon by extruding a circular section along the path to form a tie. It is an element of 4 nodes with 6 degrees of freedom in each node. The shell element was also used to model the bottom flange of $240 \mathrm{~mm}$ wide at the ends of the beam.

Table 1. Cross-section and parameters of the analysed pre-stressed concrete beam with the span of $12 \mathrm{~m}$

\begin{tabular}{|c|c|c|c|c|c|c|c|}
\hline $\begin{array}{c}\text { Name of } \\
\text { strand }\end{array}$ & $\begin{array}{c}\text { Diameter } \\
\mathbf{d}[\mathbf{m m}]\end{array}$ & $\begin{array}{c}\text { Cross } \\
\text { sectioned } \\
\text { area Sn } \\
{\left[\mathbf{m m}^{2}\right]}\end{array}$ & $\begin{array}{c}\text { Nominal } \\
\text { mass } \mathbf{M} \\
{[\mathbf{g} / \mathbf{m}]}\end{array}$ & $\begin{array}{c}\text { Tensile } \\
\text { strength } \\
\mathbf{R}_{\mathbf{m}}[\mathbf{M P a}]\end{array}$ & $\begin{array}{c}\text { Characteristic } \\
\text { value } \\
\text { of max force } \\
\mathbf{F}_{\mathbf{m}}[\mathbf{k N}]\end{array}$ & $\begin{array}{c}\text { Characteristic } \\
\text { value of 0.1\% } \\
\text { proof force } \\
\mathbf{F p}_{0.1}[\mathbf{k N}]\end{array}$ & \\
\hline Y1860S7 & 8.0 & 38.0 & 296.8 & 1860 & 70.7 & 62.2 & \\
\hline
\end{tabular}



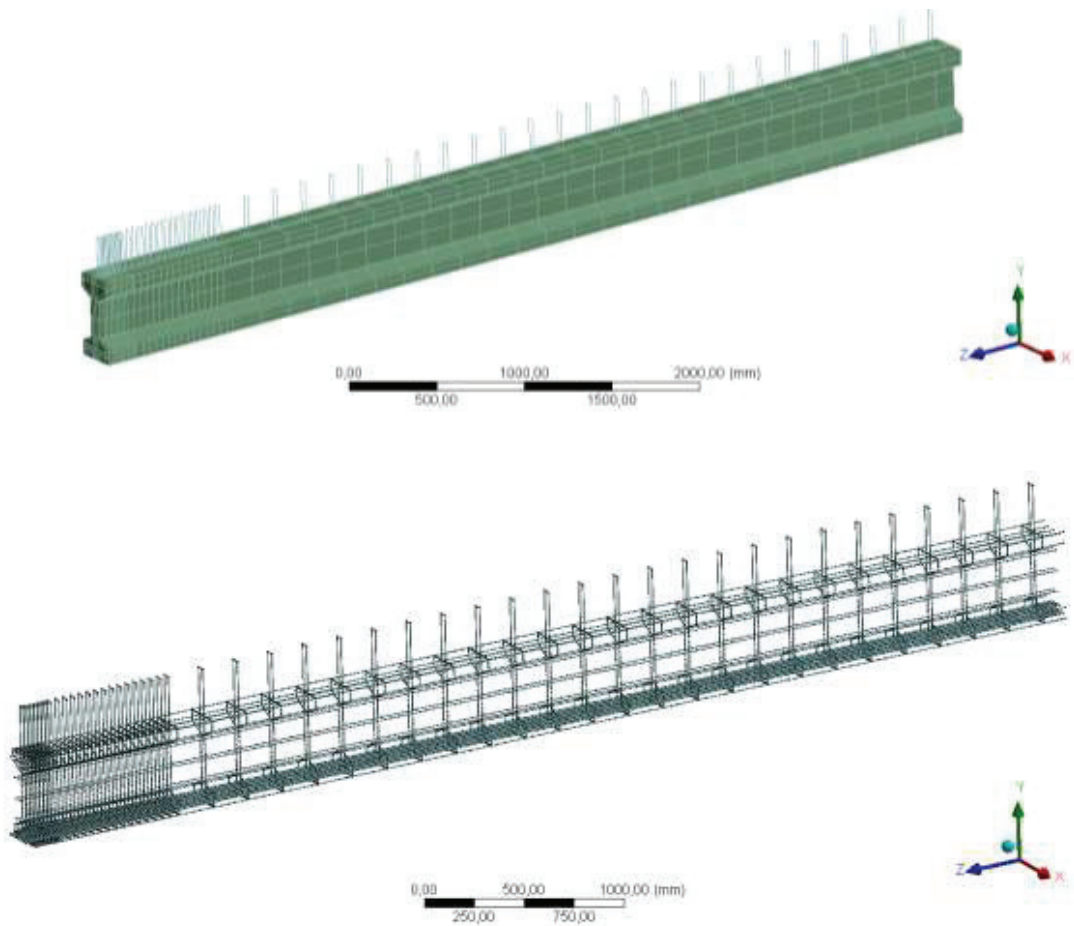

Fig. 1. The FEM model of the beam. Detailing for prestressing tendons and ordinary reinforcement.

\subsection{NUMERICAL ANALYSIS OF THE STRUCTURE}

During the analysis related to the pre-tensioned beam, the influence of many different parameters on the behavior of the structure (e.g. material properties, boundary conditions) can be taken into consideration but changes in geometry of the prestressing tendons and mechanical parameters during the use of the structure are the main source of variations of solutions. The analysis used tools related to the parametric design language ANSYS APDL (ANSYS Parametric Design Language) which allow the user to create parameterized geometry. It is connected with the necessity of preparing a new model from the scratch with appropriate implementation of standard formulas [14]. The set of all calculation results $y_{1}, y_{2}, \ldots, y_{k}$ indicates the scope of possible states of pre-tensioned 
concrete beam, which can be divided into acceptable solutions which meet the design criteria in different degree and those solutions that are close to the optimum $[10,11,12,15]$. The optimization criteria are usually limited to the standard requirements related to the limit state of bearing capacity and serviceability.

Acceptable solutions are based on limitations of the maximum value of prestressing force in tendons, tensile and compressive stresses in concrete [19] as well as deflections [9]. The value of immediate and long-term losses of the prestress for the assumed values of mechanical properties of materials, deformation of concrete and prestressing steel was calculated. On this basis, in the simulation calculations it was assumed that the range of prestress losses is in the range of $9-23 \%$ (for parameter S). In the MC simulation, it was the following parameters according to the table 2.

Table 2. Input parameters of the analysed pre-stressed concrete beam with a span of $12 \mathrm{~m}$

\begin{tabular}{|l|l|}
\hline Input parameters & Range of variability \\
\hline G load & {$[12 \div 18] \mathrm{kN} / \mathrm{m}$} \\
\hline S prestress losses & {$[9 \div 23] \%$} \\
\hline Y modulus of elasticity & {$[30,62 \div 36,38] \mathrm{GPa}$} \\
\hline
\end{tabular}

Prior to the correlation analysis, constraints on deflection, crack initiation, permissible stress in concrete, reinforcing and prestressing steel were introduced. In Fig. 2 a-e the above restrictions are indicated.

a)

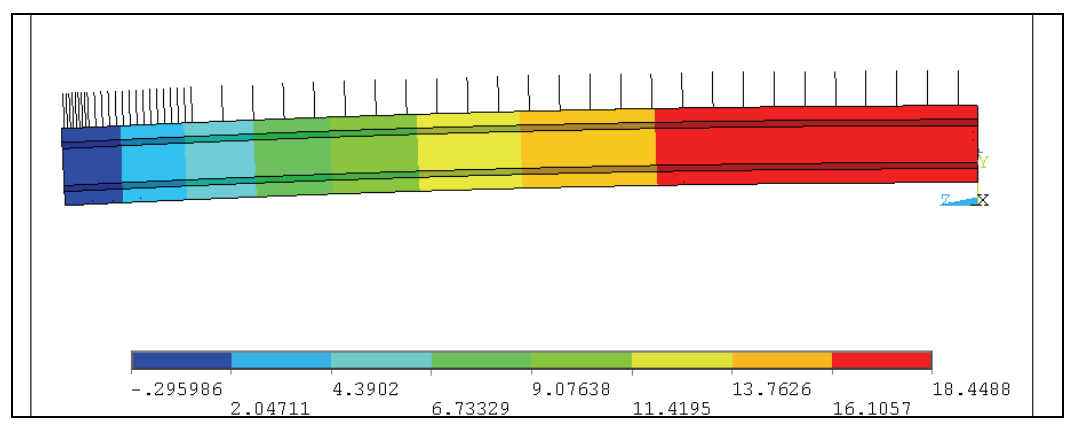


b)

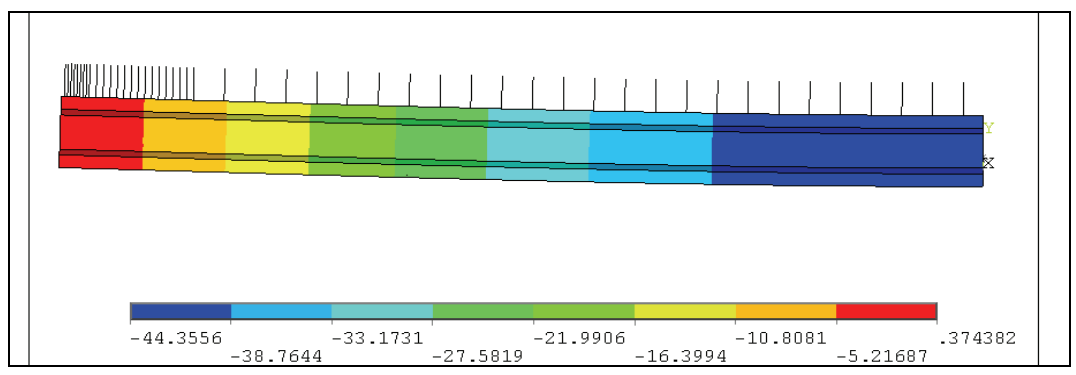

c)

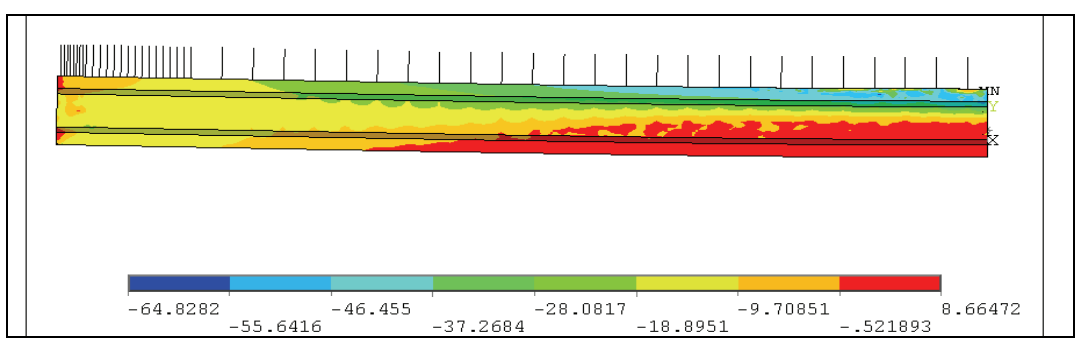

d)

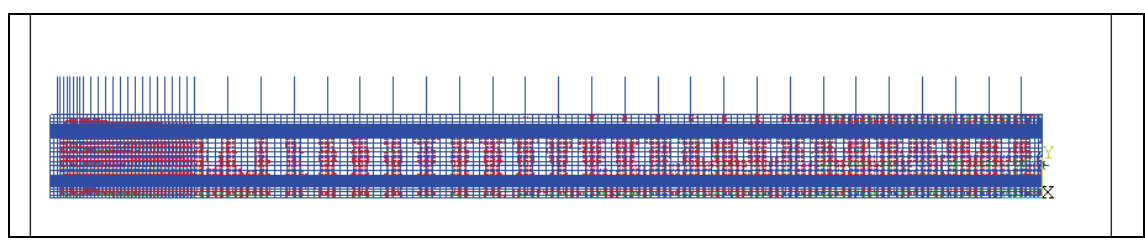

e)

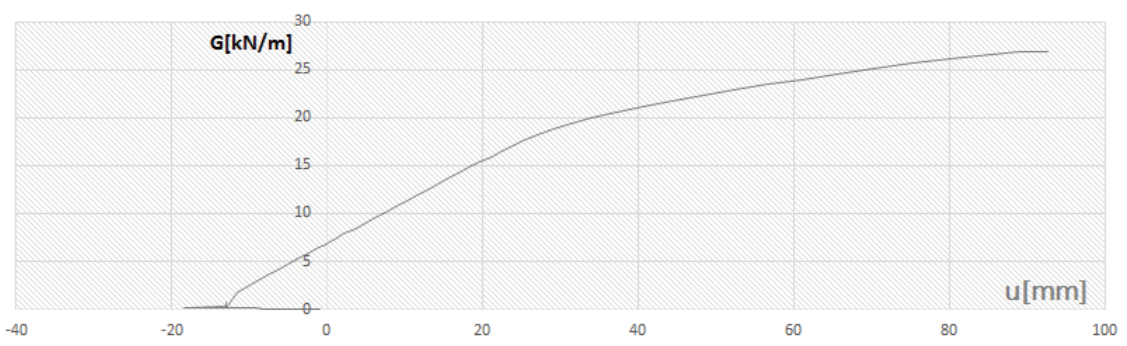

Fig. 2. Deflection $U$ of the beam in the transient (a) and persistent design situation, (b) $U_{\min }-U_{\max }$, (c), permissible stress (d), the crack start - deflection 19,8 [mm], for the minimum value of the modulus of elasticity Y [GPa], (e) deflection of the beam in the middle of the span for the maximum load $\mathrm{G}$. 


\subsection{CORRELATION ANALYSIS}

The coefficient of correlation between random variables $\mathrm{X}$ - prestressing force with prestress losses) and Y- deflection of the beam, reveals negligible correlation $\rho_{\mathrm{XY}}=0,117$, similarly between the modulus of elasticity and deflection for which the value of coefficient of correlation equals $\rho_{\mathrm{XY}} \approx$ 0,21 . Between the global safety factor and deflection the results indicate either a significant linear correlation $\rho_{\mathrm{XY}}=0,415 \div 0,7$ or very strong $\rho_{\mathrm{XY}} \geq 0,92$ in case when global safety factor GIS $>2.6$. Correlations between global safety factor GIS and other variables indicate a slight dependency but it may be justified by the fact that the trend lines for these variables are inherently non-linear (see Tab

Table 1. Correlation matrix. Input variables: total load (G), the presstresing force with losses in tendons (S), modulus of elasticity depending on the concrete age (Y), and output variables: deflection of the beam (U) and global safety factor (GlS), for number of simulations steps $10^{\wedge} 5$

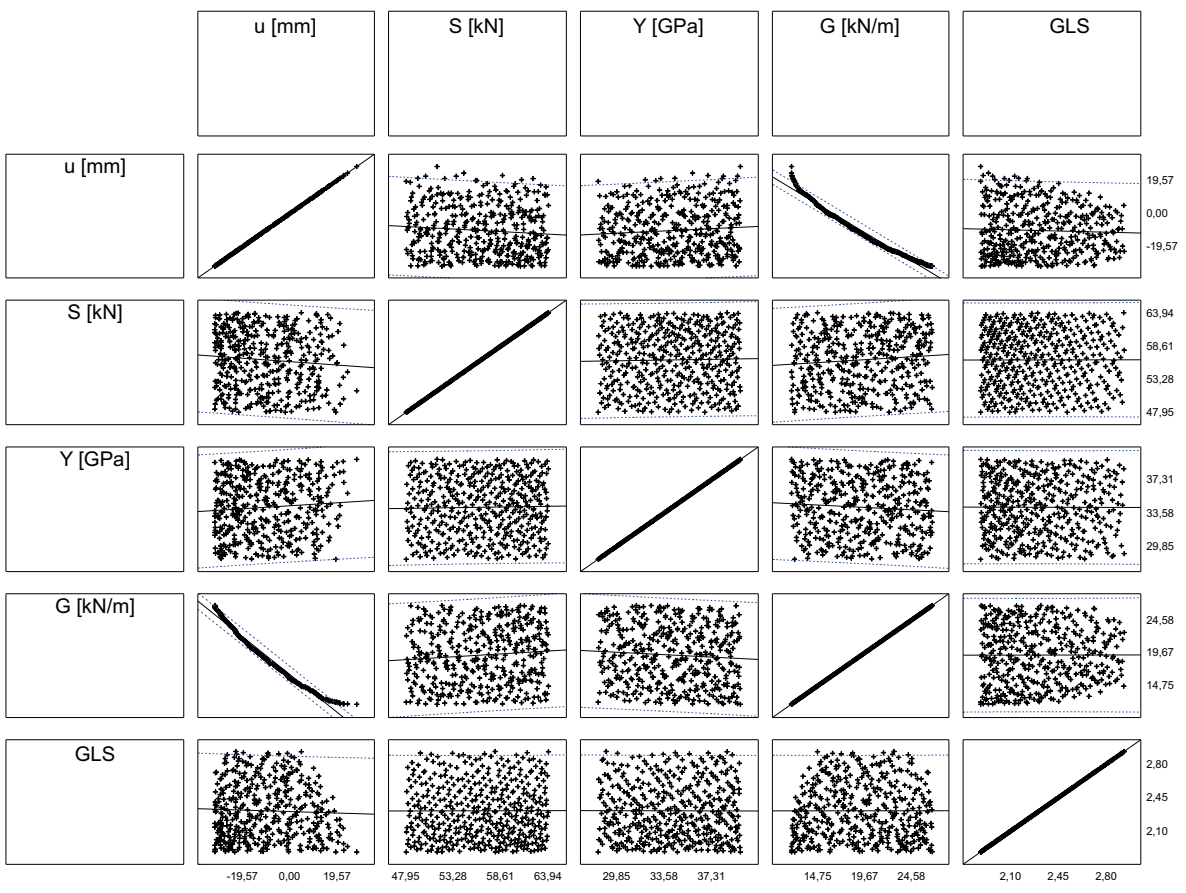

$\mathrm{S}[\mathrm{kN}]: \mathrm{u}[\mathrm{mm}]: \mathrm{r}=0.1168 ; \mathrm{Y}[\mathrm{GPa}]: \mathrm{u}[\mathrm{mm}]: \mathrm{r}=0.2101 ; \mathrm{G}\left[\mathrm{kN} / \mathrm{m}^{2}\right]: \mathrm{u}[\mathrm{mm}]: \mathrm{r}=-0.9874 ; \mathrm{GLS}: \mathrm{u}[\mathrm{mm}]: \mathrm{r}=-0.4147 ; \mathrm{u}[\mathrm{mm}]: \mathrm{S}[\mathrm{kN}]:$ $\mathrm{r}=0.1168 ; \mathrm{S}[\mathrm{kN}]: \mathrm{S}[\mathrm{kN}]: \mathrm{r}=1.0000 ; \mathrm{Y}[\mathrm{GPa}]: \mathrm{S}[\mathrm{kN}]: \mathrm{r}=0.0119 ; \mathrm{G}\left[\mathrm{kN} / \mathrm{m}^{2}\right]: \mathrm{S}[\mathrm{kN}]: \mathrm{r}=-0.1222 ; \mathrm{GLS}: \mathrm{S}[\mathrm{kN}]: \mathrm{r}=0.0148 ; \mathrm{u}$ $[\mathrm{mm}]: \mathrm{Y}[\mathrm{GPa}]: \mathrm{r}=0.0 .2101 ; \mathrm{S}[\mathrm{kN}]: \mathrm{Y}[\mathrm{GPa}]: \mathrm{r}=0.0119 ; \mathrm{Y}[\mathrm{GPa}]: \mathrm{Y}[\mathrm{GPa}]: \mathrm{r}=1.0000 ; \mathrm{G}\left[\mathrm{kN} / \mathrm{m}^{2}\right]: \mathrm{Y}[\mathrm{GPa}]: \mathrm{r}=-0.0937 ; \mathrm{GLS}: \mathrm{Y}$ [GPa]: $\mathrm{r}=-0.0057 ; \mathrm{u}[\mathrm{mm}]: \mathrm{G}\left[\mathrm{kN} / \mathrm{m}^{2}\right]: \mathrm{r}=-0.9874 ; \mathrm{Y}[\mathrm{GPa}]: \mathrm{G}\left[\mathrm{kN} / \mathrm{m}^{2}\right]: \mathrm{r}=-0.0937 ; \mathrm{G}\left[\mathrm{kN} / \mathrm{m}^{2}\right]: \mathrm{G}\left[\mathrm{kN} / \mathrm{m}^{2}\right]: \mathrm{r}=1.0000 ; \mathrm{GLS}: \mathrm{G}$ $\left[\mathrm{kN} / \mathrm{m}^{2}\right]: \mathrm{r}=0.4139 ; \mathrm{u}[\mathrm{mm}]: \mathrm{GLS}: \mathrm{r}=-0.4147 ; \mathrm{S}[\mathrm{kN}]: \mathrm{GLS}: \mathrm{r}=0.0148 ; \mathrm{Y}[\mathrm{GPa}]: \mathrm{GLS}: \mathrm{r}=-0.0057 ; \mathrm{G}\left[\mathrm{kN} / \mathrm{m}^{2}\right]: \mathrm{GLS}: \mathrm{r}=0.4139 ;$ GLS:GLS:r $=1.0000$ 


\subsection{ANALYSIS OF SENSITIVITY}

Knowing the response surface allows to analyze parametric sensitivity of the structure to changes in design variables, defining acceptable range of input variables for which design requirements are met, and selecting optimal combination of these variables in terms of established requirements and criteria. In the case of the analyzed pre-tensioned concrete beam, five-dimensional response surface for the adopted range of 3 input variables and 2 output variables was approximated by the MC simulation method. As the output variables, global safety factor G1S and the maximum deflection of the analyzed beam were adopted, which are decisive for meeting basic safety and serviceability requirements of the structure. To use a multidimensional response hyper-surface for practical sensitivity analysis, which means to choose a design solution close to the optimum or to verify a particular solution, two or three-dimensional cross-sections can be used. This is the so-called "whatif" or "trade-off graphs" analysis. Fig. 3 shows a three-dimensional cross-section of the hypersurface of the analyzed G-Y-U variables (load - the modulus of elasticity Y - deflection). On the basis of the "what-if" analysis we check how the beam's values of deflection changes. For example, for load $\mathrm{G}=18 \mathrm{kN} / \mathrm{m}$, elastic modulus $\mathrm{Y}$ is situated in the range from $30-40 \mathrm{GPa}$, changes in deflection range for the modulus $\mathrm{Y}=30 \mathrm{Gpa}$ - deflection will be $11.41 \mathrm{~mm}$, and with the modulus $\mathrm{Y}=40 \mathrm{GPa}$, deflection will be $9.81 \mathrm{~mm}$. A strong tendency for increase values of the safety factor in combination with reduction of deflection is confirmed by the correlation coefficient between these variables $\rho>0.9$. It can also be seen that for the global safety factor, GlS $=2,6$ deflection will be $5,0 \mathrm{~mm}$ with an average load of $12 \mathrm{kN} / \mathrm{m}$ (see fig. 5).

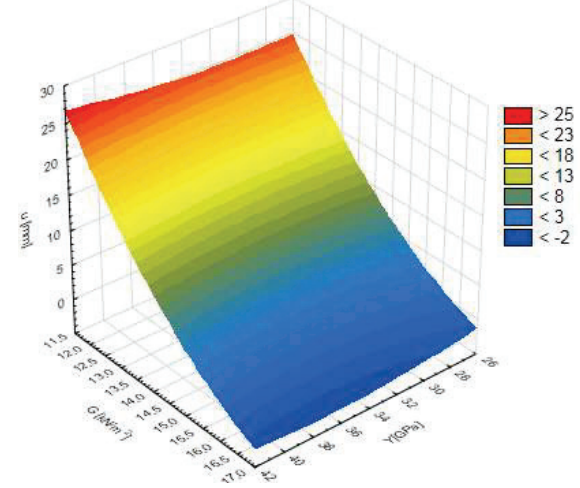

Fig. 3. Cross-section of the response hyper-surface of the considered beam for variables U-G-Y, $\mathrm{U}=79,1224+0,0583 \mathrm{Y}-5,1277 \mathrm{G}$ 


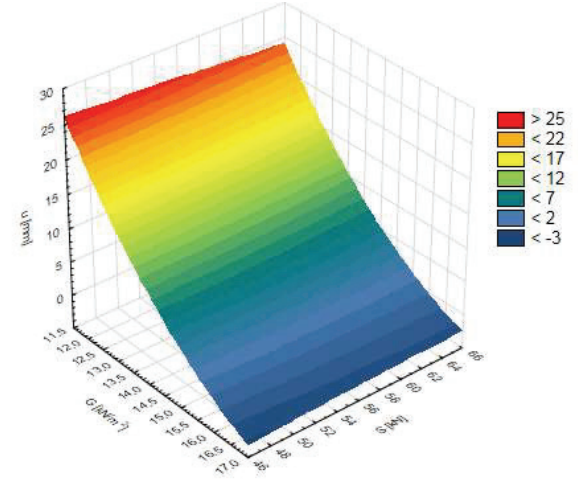

Fig. 4. The cross-section of response hyper-surface of the considered beam for the variables U-G-S; $U=83,0978$ 5,1406S-0,0318G

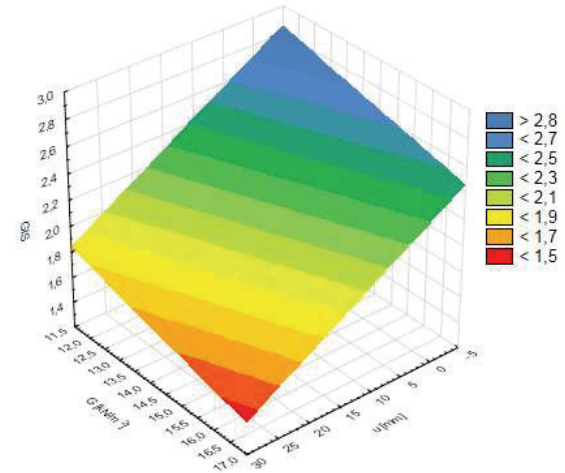

Fig.5. The cross-section of the response hyper-surface of the considered beam for the variables U-G-GIS; GIS = 3,5396$0,0291 \mathrm{U}-0,0718 \mathrm{G}$

The determined response surface of the structure can also be used to search for solutions that are close to optimum in terms of the state or output variables (multi-criteria optimization). The more design points are used to determine the response surface, the solution is closer to the optimal. The more number of the design points are used to determine the response surface, the solution is closer to the optimal solution. In the presented virtual experiment, the number of output data were $10^{\wedge} 4 \mathrm{r}$. Another simpler way to use response surface of the structure is to draw up trade-off graphs. They represent sets of output values of variable, and a surface of input variables which are divided into an area of acceptable and unacceptable solutions, in relation to the values of output variables. Coordinates of points representing possible solutions of construction for specific ranges of changes in variables of the analysis can be also determined on the basis of the response surface. 
Trade-off graphs can be used, among others, for quick verification of the influence of assumed and modified values of design variables on the output variables. The dividing line between the safe and the unsafe area corresponds to a $21.3 \mathrm{~mm}$ deflection value. The set of solutions due to the assurance of GlS $>2.6$ is presented in the graph in blue.

Trade-off graph between deflection $\mathrm{U}[\mathrm{mm}]$ and the global safety factor G1S is presented in Figure 6. Here again the dividing line between the area of permissible deflections was provided for the deflection value $11.6 \mathrm{~mm}$. The area corresponding to the value of the safety factor G1S>2.60 is marked in blue.

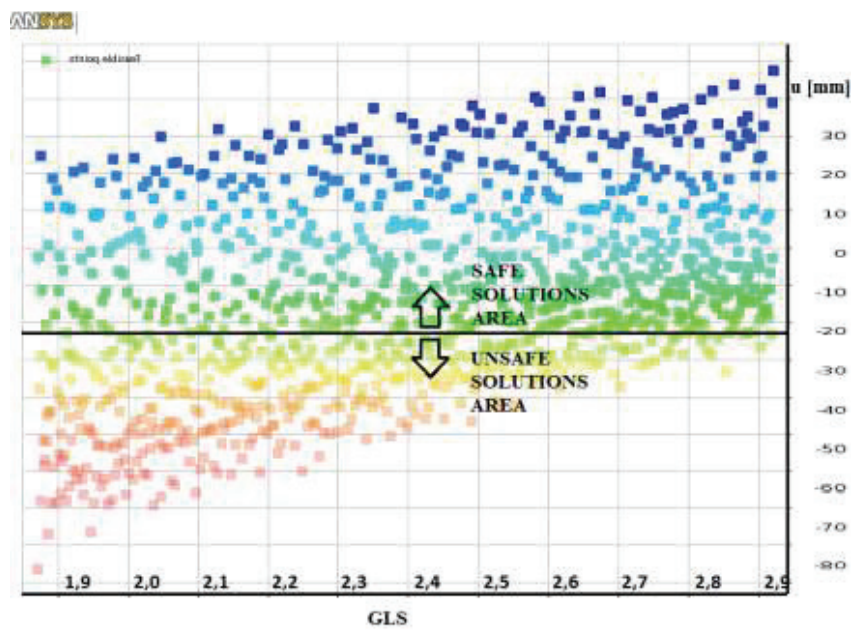

Fig. 6. Trade-off graph between global deflection $U[\mathrm{~mm}]$ and global safety GiS in the persistent design situation.

\section{CONCLUSIONS}

Development in design and optimization theories and the automation of calculations increase the expectations of designers and investors in the implementation of effective and transparent design procedures for building facilities that meet numerous detailed requirements for construction, function, durability, environment, economy and other aspects of design.

The multiaspectual nature of requirements and the associated large number of project variables and optimization criteria, which are burdened with significant uncertainties of a different nature and are difficult to quantify, cause the design practice to be dominated by the approach based on 
verification and correction of the preliminary design and the finally obtained results are only intuitively similar to the optimal design.

The approach presented in this paper based on the parametric analysis of the structural sensitivity using the DOE simulation technique allows for identification of variables deciding about the effectiveness and economy of designed structures.

The use of the hyper-surface of the construction response enables designers to the development of three- or two-dimensional trade-off graphs facilitates the assessment of the scope of changes in random state variables permitted due to the adequate criteria and selection of their values close to optimum.

\section{REFERENCES}

1. Sz. Woliński, T. Pytlowany. „Analysis of the state of prestressed structure using data collection simulation technique. January 2019 MATEC Web of Conferences 262(3): 08006 DOI: 10.1051/ matecconf $/ 201926208006$

2. J. Stadnicki Theory and practice of solving optimization tasks with examples of technical applications (in Polish). Warszawa WNT, Warszawa, (2006).

3. C. Szymczak Elements of design theory (in Polish) PWN, Warszawa, (1998).

4. N. Bradley The Response Surface Methodology. Indiana University, South Bend, 2007.

5. ANSYS Programme, ANSYS Design Xplorer Module ver. Research v19 2018.

6. J.C. Helton Latin hypercube sampling and the propagation of uncertainty in analyses of complex systems. Reliability Engineering and System Safety, 81: 23-69, (2003).

7. M. Korzyński: Experiment methodology (in Polish) Publishing house N-T, Warszawa, 2006.

8. L. Gajek, M. Kałuczka. Statistical Inference. Models and methods. (in Polish) Publishing house N-T, Warszawa, (1994).

9. PN-EN 1992-1-1 Design of concrete structures - Part 1-1: General rules and rules for buildings [Authority: The European Union Per Regulation 305/2011, Directive 98/34/EC, Directive 2004/18/EC

10. A. Adjukiewicz,, J. Mames Prestressed concrete structures. (in Polish) Polski Cement, Kraków, (2004).

11. L. Mikulski, Sz. Sobczyk. Optimization of prestressed beams.(in Polish) PAK vol. 58, no 10/2012. (2012).

12. S.Hernandez, A.N.FontanJ.Diaz, D.Marcos, An improved software for design optimization of prestressed concrete beams, https://doi.org/10.1016/j.advengsoft.2009.03.009 Advances in Engineering Software Volume 41, Issue 3, March 2010, Pages 415-421. (2010).

13. P. B. R. Dissanayake and S. Jothy Karma

14. Optimum Design of Prestressed Concrete Beams ENGINEER-Vol. XXXX, No. 02, pp. 29-32, 2007. (2007).

15. Z. Aydin Y. Ayvaz, Optimum topology and shape design of prestressed concrete bridge girders using a genetic algorithm Structural and Multidisciplinary Optimization February 2010, Volume 41, Issue 1, pp 151-162. (2010)

16. Ayvaz Y, Aydın Z Optimum design of trusses using a genetic algorithm. In: Proceedings of the second international conference on engineering using metaphors from nature. Leuven, Belgium, pp 159-168 (2000).

17. GIN Rozvany, A critical review of established methods of structural topology optimization. Struct Multidiscipl Optim. doi: 10.1007/s00158-007-0217-0 (2008)

18. G.F. Medeiros, M. Kripka. "Structural optimization and proposition of pre-sizing parameters for beams in 
reinforced concrete buildings", Comput. Concrete, 11(3), 253-270 (2013),

19. A. Guerra, and P.D. Kiousis, P.D. "Design optimization of reinforced concrete structures", Comput. Concrete, 3(5), 313-334. (2006),

20. Skrzypczak. I. Buda- Ożóg L., Pytlowany T. "Fuzzy method of conformity control for compressive strength of concrete on the basis of computational numerical analysis", Meccanica 51 (2), 383-389 (2016)

\section{LIST OF FIGURES AND TABLES:}

Fig. 1. The FEM model of the beam. Detailing for prestressing tendons and ordinary reinforcement.

Fig. 1. Model MES belki strunobetonowej. Rozmieszczenie cięgien sprężających i zbrojenia

Fig. 2. Deflection of the beam in the transient (a) and persistent design situation (b), Umin - Umax, (c), permissible stress (d), the crack start - deflection 19,8 [mm], for the minimum value of the modulus of elasticity $\mathrm{Y}[\mathrm{GPa}](\mathrm{e})$, deflection of the beam in the middle of the span for the maximum load G.

Fig. 2. Deflection of the beam in the transient (a) and persistent design situation (b) $-U_{\min }-U_{\max }$. (c) permissible stress, (d) beginning of the crack start - deflection 19.8 [mm] for the minimum value of the modulus of elasticity Y[GPa]] (e) deflection of the beam in the middle of the span for the external load G.

Rys. 2. Ugięcie (a) w trwałej sytuacji i przejściowej (b) -Umin - Umax. (c) dopuszczalne naprężenie, (d) początek początku inicjacji rysy - ugięcie 19,8 [mm] dla minimalnej wartości modułu sprężystości Y [GPa]] (e) ugięcie belki w środku rozpiętości dla obciążenia G .

Tab 1. Cros-section and parameters of the analysed pres-stressed concrete beam with a span of $12 \mathrm{~m}$.

Tab 1. Przektój analizowanej belki strunobetonowej $12 \mathrm{~m}$ oraz parametry splotów

Tab 2. Correlation matrix. Input variables: total load $(\mathrm{G})$, the presstresing force including losses in the cable (S), modulus of elasticity depending on the concrete age $\mathrm{Y}$ and output variables: beam deflection (U) and global safety factor (G1S) - simulation $10^{\wedge} 5$

Tab. 2. Macierz korelacji. Zmienne wejściowe: obciążenie całkowite (G), siła wstępnego naprężenia obejmująca straty w kablu (S), moduł sprężystości w zależności od konkretnego wieku Y i zmienne wyjściowe: odchylenie wiązki (U) i globalny współczynnik bezpieczeństwa (GIS) symulacja $10^{\wedge} 5$

Fig. 3. Cross-section of the response hyper-surface of the analyzed beam for variables U-G-Y , U = $79,1224+0,0583 * \mathrm{Y}-5,1277 * \mathrm{G}$

Rys. 3. Przekrój hiper-powierzchni analizowanej belki dla zmiennych U-G-Y, $U=$ $79,1224+0,0583 * \mathrm{Y}-5,1277 * \mathrm{G}$ 
Fig. 4. The cross-section of response hyper-surface of the analyzed beam for the variables U-G-S; $\mathrm{U}=83,0978-5,1406 * \mathrm{~S}-0,0318 * \mathrm{G}$.

Rys. 4. Przekrój hiper-powierzchni analizowanej belki dla zmiennych U-G-S; U $=83,0978$ $5,1406 * \mathrm{~S}-0,0318 * \mathrm{G}$

Fig 5. The cross-section of the response hyper-surface of the analyzed beam for the variables U-GG1S; GIS = 3,5396-0,0291U-0,0718G

Rys. 5. Przekrój hiper-powierzchni analizowanej belki dla zmiennych U-G-GlS; GIS =3,53960,0291U-0,0718G

Fig. 6. Trade-off graph between the global safety factor GlS and the Young's modulus Y [GPA] in the persistent design situation.

Rys. 6. Wykres frontu rozwiązań między globalnym współczynnikiem bezpieczeństwa GIS, a modułem Younga Y [GPA] w trwałej sytuacji projektowej. 


\section{PARAMETRYCZNA ANALIZA WRAŻLIWOŚCI BELKI STRUNOBETONOWEJ ZA POMOCĄ TECHNIKI SYMULACYJNEJ DOE}

Keywords: technika DOE, belka strunobetonowa, ocena wrażliwości, niezawodność konstrukcji

W artykule przedstawiono metodę analizy wpływu zmiennych wejściowych na parametry charakteryzujące stan konstrukcji sprężonych w początkowej i trwałej sytuacji obliczeniowej, opartą na symulacjach komputerowych $i$ technice zbierania informacji DOE (Design Of Experiments). Założenia, procedury i wyniki zastosowania techniki DOE przedstawiono na przykładzie belki strunobetonowej zaprojektowanej zgodnie $\mathrm{z}$ wymaganiami Eurokodu 2. Przeprowadzono analizę typu ,what-if” wpływu wartości obciążenia i siły sprężającej w poszczególnych cięgnach (uwzględniając straty wynikające $\mathrm{z}$ relaksacji stali sprężającej) oraz modułu sprężystości podłużnej betonu na nośność graniczną i maksymalne ugięcie belki.

Kryteria optymalizacji ograniczono do wymagań normowych związanych ze stanami granicznymi nośności i użytkowalności. Dopuszczalne rozwiązania wynikały $\mathrm{z}$ ograniczeń dotyczących wartości maksymalnej siły naciągu cięgien, naprężeń w betonie i ugięć. Wykorzystany do obliczeń moduł ANSYSDesignXproler programu ANSYS wybiera punkty projektowe według planu eksperymentu opartego na metodzie hipersześcianu łacińskiego. Próbkowanie tego typu jest jedną z najbardziej efektywnych metod generowania próbek losowych możliwych do uzyskania z funkcji gęstości rozkładu prawdopodobieństwa składowych n-wymiarowego wektora losowego i umożliwia wiarygodne oszacowanie poziomu korelacji uwzględnionych w analizie

W odniesieniu do analizowanej belki kablobetonowej pięciowymiarową hiperpowierzchnię odpowiedzi dla przyjętego zakresu 3 zmiennych wejściowych i 2 wyjściowych aproksymowano z wykorzystaniem metody symulacji MC. Jako zmienne wyjściowe, czyli decydujące o spełnieniu podstawowych wymagań dotyczących bezpieczeństwa i użytkowalności konstrukcji, przyjęto globalny współczynnik bezpieczeństwa $s$ i maksymalne ugięcie belki.

Przedstawione w pracy podejście do analizy stanu konstrukcji polega na zastosowaniu symulacyjnej techniki zbierania danych w celu aproksymacji hiperpowierzchni odpowiedzi konstrukcji umożliwiającej identyfikację kluczowych zmiennych projektowych decydujących o stanie bezpieczeństwa konstrukcji, określenie granic dopuszczalnych i zbliżonych do optymalnych stanów konstrukcji oraz wyboru zbliżonych do optymalnych. 